\title{
Usefulness of Serum IGF-I and IGFBP-3 Levels in Children with Short Stature
}

Young Su Je', Woo Ri Jang $^{1}$, Chung Hyun $\mathrm{Nahm}^{1}$, Jong Won Choi $^{1}$, Jin Ju Kim ${ }^{1}$, Soon Ki Kim², Ji Eun Lee $^{2}$, In Young Hyun ${ }^{3}$, and Yeonsook Moon ${ }^{1}$ Departments of ${ }^{1}$ Laboratory Medicine, ${ }^{2}$ Pediatrics, and ${ }^{3}$ Nuclear Medicine, Medical School of Inha University, Incheon, Korea

Corresponding author: Yeonsook Moon Department of Laboratory Medicine, Inha University Hospital, Inha University School of Medicine, 27 Inhang-ro, Junggu, Incheon 400-711, Korea Tel: +82-32-890-2523 Fax: +82-32-890-2529 E-mail: moonys@inha.ac.kr
Background: Serum insulin-like growth factor-I (IGF-I) and insulin-like growth factor binding protein-3 (IGFBP-3) levels are known markers of growth hormone (GH) secretion. The clinical utility of serum IGF-I and IGFBP-3 testing, however, remains controversial. The aims of this study were to evaluate the usefulness of IGF-I and IGFBP-3 as indicators of GH secretion through the GH stimulation test and to investigate whether a decrease in serum IGF-I levels in children with short stature, regardless of the cause, can be used as a screening test for short stature.

Methods: A total of 262 children presented with short stature, precocious puberty, or premature thelarche and were grouped into 7 tiers based on the 2007 growth chart. Serum IGF-I and IGFBP-3 levels and GH stimulation were analyzed using an immunoradiometric assay, and the data from 68 children who were below the $3 \mathrm{rd}$ percentile for height were used to evaluate the usefulness of IGF-I and IGFBP-3 as markers of GH status.

Results: GH deficiency was confirmed by the GH stimulation test in 25 of the 68 children, and $15(15 / 25,60 \%)$ and $4(4 / 25,16 \%)$ of them showed a decrease in IGF-I and IGFBP-3 levels, respectively. The sensitivity and specificity for predicting GH secretion were $60 \%$ and $16 \%$, respectively, for IGF-1 and $41.9 \%$ and $97.7 \%$, respectively, for IGFBP-3. Decreased serum IGF-I levels were more frequently observed in children below the 25 th percentile than in those in the 25th to 95th percentiles.

Conclusions: IGF-I and IGFBP-3 levels have been used as a screening tool for GH secretion in children with short stature, but based on the results of the GH stimulation test in the current study, the levels of IGF-I and IGFBP-3 might not be useful as markers of GH secretion. Evaluating serum IGF-I levels alone is not a sufficient screening test for children with a short stature.

(J Lab Med Qual Assur 2014;36:48-53)

Key Words: Insulin-like growth factor I, Insulin-like growth factor binding protein 3, Short stature, Growth hormone

Received October 10, 2013, Revision received December 6, 2013, Accepted January 12, 2014
서론

저신장은 하나의 질환이기보다는 다양한 원인으로 발생하는 현상으로 신장이 같은 연령, 같은 성별의 평균 신장보다 3 백 분위수 미만일 경우 또는 $-2.0 \mathrm{SD}$ (표준편차)보다 작은 경우 를 말한다 [1,2]. 임상에서는 저신장증의 원인을 찾기 위해 가 족력, 성장환경, 영양상태, 선천성대사이상질환 유무 등을 알 아보고, 성장호르몬 관련 검사, 갑상샘호르몬검사, 유전자검 사 등의 진단적 검사를 시행한다. 그 중 성장호르몬은 뇌하수 체에서 박동성으로 분비되기 때문에 한번 측정한 검사결과는
의미가 없으며 24시간 동안 일정 간격으로 채혈하여 그 농도 를 검사하거나 2가지 이상의 약물을 통한 유발검사를 시행한 다 [3,4]. 그러나 성장호르몬자극검사의 번거로운 과정과 자연 적인 생체 내의 성장호르몬 분비를 반영하지 못한다는 점 등으 로 인하여, 일중 변동이 거의 없고 내인성 성장호르몬 분비상 태를 잘 반영하는 인슐린양 성장인자 I (insuline like growth factor-I, IGF-I)과 인슐린양 성장인자 결합단백-3 (insulin like growth factor binding protein-3, IGFBP-3)이 성장호르 몬 결핍증의 진단에 유용한 선별검사로 이용되고 있다 $[5,6]$. 하지만 이 두 검사에 대한 민감도와 특이도가 보고자마다 달라 
서 성장평가로서의 의의에 논란이 있어왔고[7-9] 각각 단독으 로 검사를 시행하거나 병합으로 측정하여도 성장호르몬 결핍 의 효과적인 선별검사가 되지 못한다는 보고도 있다[10]. 이에 저자들은 한국소아표준발육표 2007의 분류표상 3 백분위수 미 만의 저신장증을 주소로 내원한 16 세 미만의 소아들 중 성장 호르몬자극검사를 시행한 소아들을 대상으로 혈중 성장호르 몬 농도 지표로써의 혈중 IGF-I, IGFBP-3 농도의 임상적 유 용성을 알아보았다.

또한 IGF-I 농도가 성장호르몬 결핍과 연관되지 않은 특발 성 저신장증에서도 의미 있게 낮다는 보고[11]가 있어, 원인에 관계없이 저신장증을 주소로 내원한 소아들에서 IGF-I의 농도 를 측정하여 저신장증 지표로써의 이용가능성을 알아보기 위 해 한국소아표준발육표 2007의 분류표상 7 개의 각 군별 감소 빈도를 비교하였다.

\section{대상 및 방법}

\section{1. 대상 환자}

2009년 1월부터 2012년 12월까지 저신장으로 내원한 소아 중 한국소아표준발육표 2007에 의거하여 3 백분위수 미만의 환자 68명(남아 33명, 여아 35명, 연령분포 1-16세)을 대상 으로 IGF-I, IGFBP-3, 성장호르몬자극검사를 시행하였다. 저 신장증으로 내원한 소아 180 명과 성조숙증, 유방조기발육 등 저신장증 이외의 원인으로 성장발달에 관한 평가를 받기 위해 내원한 소아 82명을 포함한 총 262명(남아 70명, 여아 192명, 연령분포 1-16세)을 대상으로 혈청 IGF-I 농도를 측정하였 다. 소아들은 한국소아표준발육표 2007에 의거하여 일곱 개의 군으로 나누었고(Table 1), 각 군별 남아의 수가 충분치 않아

Table 1. Study participants stratified by height

\begin{tabular}{lrrrc}
\hline $\begin{array}{c}\text { Height } \\
\text { (percentile) }\end{array}$ & Male & Female & Total & $\begin{array}{c}\text { Cumulative } \\
\text { total }\end{array}$ \\
\hline $0-3$ & 56 & 89 & 145 & 145 \\
$3-5$ & 2 & 17 & 19 & 164 \\
$5-10$ & 4 & 4 & 8 & 172 \\
$10-25$ & 1 & 9 & 10 & 182 \\
$25-50$ & 3 & 17 & 20 & 202 \\
$50-75$ & 1 & 25 & 26 & 228 \\
$75-95$ & 3 & 31 & 34 & 262 \\
Total & 70 & 192 & 262 & \\
\hline
\end{tabular}

${ }^{\star}$ Height groups were based on the 2007 Korean National Growth Charts.
남녀 구별 없이 각 군별 감소빈도를 조사하였다.

\section{2. 방법}

신장의 계측은 일어설 수 없는 소아의 경우에는 신생아/유 아용 신장체중 자동측정기를 이용하여 측정하였고, 일어설 수 있는 소아의 경우에는 일반 신장체중 측정기를 이용하여 측 정하였다. 대상 소아들에서 채취한 전혈은 즉시 원심분리하 여 검사를 시행할 때까지 $-70^{\circ} \mathrm{C}$ 이하에서 냉동 보관하였다. 혈 청 IGF-I 농도와 IGFBP-3 농도는 면역방사측정(IRMA)키트 (Immunotech; Beckman Coulter, Marseille, France)을 이 용하여 측정하였다. 두 검사 모두 각 소아의 연령별 참고치가 달라서 동일한 기준치를 적용할 수 없으므로 시약회사에서 제 공하는 연령별 참고치에 비교하여 증가 혹은 감소 여부를 판정 하였고 성장호르몬자극검사를 시행한 소아에서 증가, 감소의 빈도를 조사하였다. 성장호르몬자극검사는 성장호르몬 분비 를 자극하는 자극제를 투여하지 않은 상태에서 측정을 하고 자 극제인 levodopa 투여 후 60, 90, 120분에, 인슐린 투여 후 30, 60,90 분에, 글루카곤 투여 후 $90,120,180$ 분에 성장호르몬을 측정(HGH-CTK IRMA kit; DiaSorin SpA, Vercelli, Italy) 하였다. 성장호르몬 결핍기준은 각 자극제 투여 후 측정한 성 장호르몬 수치가 한 번도 $10 \mathrm{mU} / \mathrm{L}$ 이상으로 측정된 적이 없 을 때로 하였다. 저신장증과 정상 신장을 갖는 다른 성장 관련 증상(성조숙증, 조기유방발육 등)을 주소로 내원한 소아들을 대상으로 IGF-I을 측정하여 7개군 간의 감소빈도를 비교하였 다.

\section{3. 통계분석}

성장호르몬자극검사결과와 IGF-I, IGFBP-3 감소빈도의 통계학적 유의성을 확인하고, 7 개의 각 군별 소아들 간 혈중 IGF-I 농도의 감소빈도 차이를 분석하기 위해 Pearson 카이 제곱검정을 시행하였다. 자료의 분석은 SAS ver. 8.2 (SAS Institute Inc., Cary, NC, USA) 프로그램을 사용하였다. 통 계학적 유의성은 $P<0.05$ 로 정의하였다.

\section{결과}

\section{1. 성장호르몬자극검사결과와 IGF-I, IGFBP-3 혈중농도}

성장호르몬자극검사를 시행한 68 명 중 25 명은 자극제에 대 해 반응하지 않아 성장호르몬 결핍으로 진단하였으며 이들 중 15 명 $60 \%)$ 에서 IGF-I이 감소되어 있었다. 43 명은 정상반응 을 보였고 이 중 25 명 $(58.1 \%)$ 에서 IGF-I이 감소되어 있었다. 성장호르몬자극검사결과 성장호르몬 결핍증을 진단받은 군과 


\section{Journal of LABORATORY MEDICINE and QUALITY ASSURANCE}

\section{Young Su Je et al • Usefulness of IGF-I and IGFBP-3 in Short Stature}

Table 2. Incidence of decreased serum IGF-1 levels by growth hormone secretion levels in children below the 3rd percentile for height

\begin{tabular}{cccc}
\hline $\begin{array}{c}\text { Growth hormone } \\
\text { secretion levels }\end{array}$ & $\begin{array}{c}\text { Normal } \\
\text { IGF-I }\end{array}$ & $\begin{array}{c}\text { Decreased } \\
\text { IGF-I }\end{array}$ & $P$-value \\
\hline $\begin{array}{c}\text { Growth hormone deficiency } \\
(\mathrm{n}=25)\end{array}$ & 10 & 15 & $0.881^{*}$ \\
$\begin{array}{c}\text { Normal growth hormone } \\
(\mathrm{n}=43)\end{array}$ & 18 & 25 & \\
\hline
\end{tabular}

Abbreviation: IGF-I, insuline like growth factor-I.

${ }^{\star}$ By chi-square test.
Table 3. Incidence of decreased serum IGFBP-3 levels by growth hormone secretion levels in children below the $3 \mathrm{rd}$ percentile for height

\begin{tabular}{cccc}
\hline $\begin{array}{c}\text { Growth hormone } \\
\text { secretion levels }\end{array}$ & $\begin{array}{c}\text { Normal } \\
\text { IGFBP-3 }\end{array}$ & $\begin{array}{c}\text { Decreased } \\
\text { IGFBP-3 }\end{array}$ & $P$-value \\
\hline $\begin{array}{c}\text { Growth hormone deficiency } \\
(\mathrm{n}=25)\end{array}$ & 21 & 4 & $0.037^{\star}$ \\
$\begin{array}{c}\text { Normal growth hormone } \\
(\mathrm{n}=43)\end{array}$ & 42 & 1 & \\
\hline
\end{tabular}

Abbreviation: IGFBP-3, insuline like growth factor binding protein-3. ${ }^{*}$ By chi-square test.

Table 4. Frequency of decreased serum IGF-1 levels in 262 children

\begin{tabular}{ccccc}
\hline Height (percentile) & Normal IGF-I levels & Decreased IGF-I levels & Incidence (\%) & Cumulative incidence $(\mathrm{n}, \%)$ \\
\hline $0-3$ & 74 & 71 & 49.0 & $71 / 145(49.0)$ \\
$3-5$ & 12 & 7 & 36.8 & $78 / 164(47.6)$ \\
$5-10$ & 3 & 5 & 62.5 & $83 / 172(48.3)$ \\
$10-25$ & 5 & 5 & 50.0 & $88 / 182(48.4)$ \\
$25-50$ & 19 & 1 & 5.0 & $89 / 202(44.1)$ \\
$50-75$ & 23 & 3 & 11.5 & $92 / 228(40.4)$ \\
$75-95$ & 31 & 3 & 8.8 & $95 / 262(36.3)$ \\
Total & 167 & 95 & 36.3 & \\
\hline
\end{tabular}

Abbreviation: IGF-I, insuline like growth factor-I.

정상반응을 보인 군에서 $\mathrm{IGF}-\mathrm{I}$ 감소빈도의 차이는 통계적으로 유의하지 않았다 $(P=0.881$ ) (Table 2). IGFBP-3는 성장호 르몬자극검사에서 성장호르몬 결핍을 보인 환아 25 명 중 4 명 (16\%)에서, 정상반응을 보인 43명 중 1명(2.3\%)에서 감소되 어 있었고, 성장호르몬 결핍증을 진단받은 군과 정상반응을 보 인 군에서 IGFBP-3의 감소빈도 차이는 통계적으로 유의하였 다 $(P=0.037)$ (Table 3). IGF-I과 IGFBP-3의 민감도는 각각 $60 \%, 16 \%$ 이었고 특이도는 $41.9 \%, 97.7 \%$ 이었다.

\section{2. 한국소아표준발육표 2007 에 따른 각 군 간 혈청 IGF-I값의 감소 빈도}

혈중 IGF-I 농도는 총 소아 262명 중 95명에서 감소하였다. 신장 0 - 3 백분위수군의 $49 \%$ (71/145), 0-10백분위수군의 $48.3 \%$ (83/172), 0 - 25 백분위수군의 $48.4 \%$ (88/182)에서 혈 청 IGF-I값이 감소하였다. 25 백분위수 미만 군에서는 각 그룹 별로 감소된 빈도에 뚜렷한 차이는 관찰할 수 없었다. 25 백분 위수 이상 군에서는 80 명 중 7명 (8.8\%)에서 혈청 IGF-I값이 감소해 있었다 신장 3 백분위수를 포함하는 25 백분위수 미만 인 소아군에서 혈중 IGF-I의 값이 감소된 소아의 비율은 신장
25 백분위수 이상인 소아군에 비해 의미 있게 높았다 $(P<0.05)$ (Table 4).

\section{고찰}

혈중 IGF-I과 IGFBP-3 농도는 성장호르몬 혈중농도에 영 향을 받으면서 체내에서 일정한 농도를 유지하고 측정이 비 교적 용이하여, 내인성 성장호르몬 분비평가에 유용한 진 단적 지표로 알려져 있다[12]. 하지만 연구자들 간의 주장 이 달라 아직까지도 논란이 계속되고 있는데 Ranke 등[13] 은 IGF-I과 IGFBP-3의 민감도가 $75 \%, 67 \%$ 이고 특이도가 $50 \%, 32 \%$ 이지만 반복적인 측정에서 변화의 폭이 좁기 때 문에 인체계측, 영상정보와 함께 시행하면 성장호르몬 결핍 과 특발성 저신장증을 감별하는데 필요한 검사법이라고 하였 고, Hasegawa 등[14]은 성장호르몬 결핍 환자 중 부분 성장 호르몬 결핍 환자보다는 고전적인 성장호르몬 결핍 환자들 에서 IGF-I과 IGFBP-3의 민감도가 $80 \%, 93 \%$ 로 선별검사 로 좋은 지표라고 하였다. 그러나 성장호르몬 결핍증의 진단 에 IGF-I과 IGFBP-3 모두 민감도와 특이도가 좋지 않으며, 


\section{Journal of LABORATORY MEDICINE and QUALITY ASSURANCE}

\section{Young $\mathrm{Su}$ Je et al • Usefulness of IGF-I and IGFBP-3 in Short Stature}

특히 IGFBP-3의 경우 성장호르몬 결핍 소아에서도 정상값 을 보이는 경우가 많아 민감도가 떨어진다는 보고도 있다[15]. 본 연구의 결과도 이와 유사하게 IGF-I의 민감도와 특이도가 Ranke 등〔13]의 결과보다도 낮은 $60 \%, 41.9 \%$ 로 성장호르몬 결핍 환자 감별의 선별검사로 이용하기에 만족할 만한 수준을 보여주지 못하였고, IGFBP-3의 민감도와 특이도 각각 $16 \%$, $97.7 \%$ 로 특이도는 높았으나 민감도가 너무 낮아 이 또한 선별 검사로 이용하기는 어려울 것으로 판단하였다. 이는 Mitchell 등[10]이 IGF-I과 IGFBP-3 중 어느 것도 성장호르몬 결핍의 지표가 아니며, 두 가지 검사를 병행하여도 효과적인 선별검사 로 이용할 수 없다고 주장한 내용과도 일치한다. 이러한 제한 점을 갖는 이유는 IGF-I, IGFBP-3의 혈중농도가 성장호르몬 분비 외에 간기능, 신기능, 영양상태, 갑상선기능저하증, 비만, 당뇨, 사춘기의 상태, 체질량지수 등에도 영향을 받기 때문으 로 보인다[3,16,17].

이와 같이 다양한 원인이 IGF-I과 IGFBP-3의 혈중농도에 영향을 미친다는 사실에 근거하여 성장호르몬 결핍에 의한 저 신장증이 아닌 특발성 저신장증 소아를 대상으로 한 연구에 서, IGF-I, IGFBP-3 농도가 정상 대조군에 비해 특발성 저신 장증 소아군에서 의미 있게 낮았다고 하였다[11]. 이에 저자들 은 성장호르몬 결핍에 의한 저신장증, 특발성 저신장증을 포함 하는 다양한 원인에 의해 발생한 저신장증 소아들을 대상으로 IGF-I 혈중농도를 측정하고 저신장증 지표로써의 이용가능성 을 알아보기 위해 저신장증이 없는 소아들에서의 측정값과 비 교하였다. IGF-I의 연령별 성별 참고치가 달라서 절대값의 비 교보다는 참고치를 기준으로 감소, 정상, 증가로 구분하였고 한국소아표준발육표 2007에 따른 7개의 군별 감소빈도를 살 펴본 결과 25 백분위수 미만 소아군에서 25 백분위수 이상 소아 군에 비해 감소빈도가 뚜렷하게 높았다. 25 백분위수 미만 소 아에 3 백분위수 미만의 소아가 다수를 차지하고 있어 25 백분 위수까지의 IGF-I 감소빈도에 미치는 영향을 배제할 수는 없 으나 비록 숫자가 작기는 하여도 각 군별로 구별하여 감소빈도 를 비교했을 때 25 백분위수 이상 군과는 뚜렷한 차이를 보이 고 있어 의미 있는 차이를 보인다고 보았으며 3-25백분위수 소아의 수를 늘려서 확인을 해보면 더 확실한 결과를 얻을 수 있을 것으로 보인다. 저신장의 원인을 구별하지 않고 나눈 3 백 분위수 미만의 IGF-I 감소빈도(49\%)가 3백분위수 미만의 성 장호르몬 결핍 환자에서의 감소빈도 $(60 \%)$ 와 큰 차이를 보이 지 않는다는 것을 감안하면 IGF-I의 혈중농도는 성장호르몬뿐 아니라 다양한 원인에 의해 발생하는 저신장증과도 연관이 있 음을 확인할 수 있었다. 하지만 양성률이 $50 \%$ 에도 미치지 못 하고 있어 IGF-I을 저신장증의 선별검사로 사용하기는 충분치
않은 것으로 판단하였다.

본 연구에서 저자들은 성장호르몬 결핍에 의한 저신장의 선 별검사로 이용되는 IGF-I, IGFBP-3의 임상적 유용성을 알아 보기 위해 IGF-I, IGFBP-3, 성장호르몬자극검사를 시행하였 으나 성장호르몬 결핍의 지표로써는 효과적인 검사가 아니라 고 판단하였다. 또한 저신장을 주소로 내원한 소아들의 혈중 IGF-I 농도를 측정한 후 저신장증이 아닌 소아들과 비교하였 는데 3 백분위수 미만의 소아 49\% (71/145)에서 감소되어 있 어 IGF-I이 다양한 원인의 저신장증과도 연관성이 있음을 알 수 있었으나 저신장증의 선별검사로 이용하기는 어려울 것으 로 보인다.

\section{REFERENCES}

1. Lee KH. Growth assessment and diagnosis of growth disorders in childhood. J Korean Pediatr Soc 2003;46: 1171-7.

2. Cohen P, Rogol AD, Deal CL, Saenger P, Reiter EO, Ross JL, et al. Consensus statement on the diagnosis and treatment of children with idiopathic short stature: a summary of the Growth Hormone Research Society, the Lawson Wilkins Pediatric Endocrine Society, and the European Society for Paediatric Endocrinology Workshop. J Clin Endocrinol Metab 2008;93:4210-7.

3. Juul A, Skakkebaek NE. Prediction of the outcome of growth hormone provocative testing in short children by measurement of serum levels of insulin-like growth factor I and insulin-like growth factor binding protein 3. J Pediatr 1997;130:197-204.

4. Rosenfeld RG. Biochemical diagnostic strategies in the evaluation of short stature: the diagnosis of insulin-like growth factor deficiency. Horm Res 1996;46:170-3.

5. Juul A, Dalgaard P, Blum WF, Bang P, Hall K, Michaelsen KF, et al. Serum levels of insulin-like growth factor (IGF)binding protein-3 (IGFBP-3) in healthy infants, children, and adolescents: the relation to IGF-I, IGF-II, IGFBP-1, IGFBP-2, age, sex, body mass index, and pubertal maturation. J Clin Endocrinol Metab 1995;80:2534-42.

6. Jorgensen JO, Blum WF, Moller N, Ranke MB, Christiansen JS. Circadian patterns of serum insulin-like growth factor (IGF) II and IGF binding protein 3 in growth hormone-deficient patients and age- and sex-matched 


\section{Journal of LABORATORY MEDICINE and QUALITY ASSURANCE}

Young Su Je et al • Usefulness of IGF-I and IGFBP-3 in Short Stature

normal subjects. Acta Endocrinol (Copenh) 1990;123: 257-62.

7. Blum WF, Albertsson-Wikland K, Rosberg S, Ranke MB. Serum levels of insulin-like growth factor I (IGF-I) and IGF binding protein 3 reflect spontaneous growth hormone secretion. J Clin Endocrinol Metab 1993;76:1610-6.

8. Smith WJ, Nam TJ, Underwood LE, Busby WH, Celnicker A, Clemmons DR. Use of insulin-like growth factor-binding protein-2 (IGFBP-2), IGFBP-3, and IGF-I for assessing growth hormone status in short children. J Clin Endocrinol Metab 1993;77:1294-9.

9. Bereket A. Diagnosis of growth hormone deficiency: the role of growth hormone $(\mathrm{GH})$, insulin-like growth factor (IGF-I) and IGF-binding protein (IGFBP-3). J Clin Res Ped Endo 2009;1(Suppl 1):23-35.

10. Mitchell H, Dattani MT, Nanduri V, Hindmarsh PC, Preece MA, Brook CG. Failure of IGF-I and IGFBP-3 to diagnose growth hormone insufficiency. Arch Dis Child 1999;80:443-7.

11. Bae WJ, Jung JM, Chung WY. Serum levels of insulin-like growth factor-I and insulin-like growth factor binding protein-3 in children with idiopathic short stature. J Korean Soc Pediatr Endocrinol 2008;13:143-9.
12. Kim SY. Growth and sex differentiation of children born small for gestational age. Korean J Pediatr 2009;52:14251.

13. Ranke MB, Schweizer R, Elmlinger MW, Weber K, Binder G, Schwarze CP, et al. Significance of basal IGF-I, IGFBP-3 and IGFBP-2 measurements in the diagnostics of short stature in children. Horm Res 2000;54:60-8.

14. Hasegawa Y, Hasegawa T, Aso T, Kotoh S, Tsuchiya Y, Nose $\mathrm{O}$, et al. Comparison between insulin-like growth factor-I (IGF-I) and IGF binding protein-3 (IGFBP-3) measurement in the diagnosis of growth hormone deficiency. Endocr J 1993;40:185-90.

15. Tillmann V, Buckler JM, Kibirige MS, Price DA, Shalet $\mathrm{SM}$, Wales JK, et al. Biochemical tests in the diagnosis of childhood growth hormone deficiency. J Clin Endocrinol Metab 1997;82:531-5.

16. Yuksel B, Ozbek MN, Mungan NO, Darendeliler F, Budan B, Bideci A, et al. Serum IGF-1 and IGFBP-3 levels in healthy children between 0 and 6 years of age. J Clin Res Pediatr Endocrinol 2011;3:84-8.

17. Wilson DM, Stene MA, Killen JD, Hammer LD, Litt IF, Hayward C, et al. Insulin-like growth factor binding protein-3 in normal pubertal girls. Acta Endocrinol (Copenh) 1992;126:381-6. 
저신장 소아에서 인슐린양 성장인자-|와 인슐린양 성장인자 결합단백-3 혈중농도의 유용성

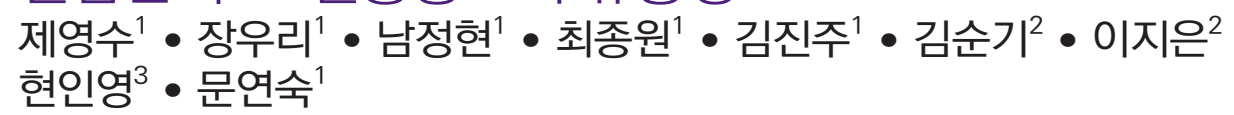

인하대학교 의학전문대학원 ${ }^{1}$ 진단검사의학교실, ${ }^{2}$ 소아청소년과학교실, ${ }^{3}$ 핵의학교실

배경: 혈청 인슐린양 성장인자 I (insuline like growth factor-I, IGF-I)과 인슐린양 성장인자 결합단 백-3 (insulin like growth factor binding protein-3, IGFBP-3)은 성장호르몬 농도에 대한 지표로 유용하다고 알려져 있다. 하지만 IGF-I과 IGFBP-3의 임상적 유용성에 대해서는 아직 논란의 여지가 있다. 이에 저자들은 성장호르몬자극검사를 통하여 성장호르몬 상태 지표로써의 IGF-I과 IGFBP-3 의 유용성을 평가하고, 원인에 관계없이 저신장을 주소로 내원한 소아를 대상으로 혈청 IGF-I의 감소 빈도를 측정하여 저신장증 선별검사로써의 이용가능성을 알아보았다.

방법: 한국소아표준발육표 2007을 기준으로 신장 3백분위수 미만인 소아 68명에서 혈청 IGF-I, IGFBP-3, 성장호르몬자극검사를 하여 IGF-|과 IGFBP-3의 성장호르몬의 상태 반영에 대한 유용성 을 평가하였다. 저신장이나 성조숙증, 유방조기발육 등이 의심되어 내원한 262 명의 소아를 대상으로 한국소아표준발육표 2007 에 따라 일곱 개의 군으로 나누어 IGF-l값을 측정한 후 각 군별 감소빈도 를 비교하였다. IGF-I, IGFBP-3, 성장호르몬 혈중농도는 면역방사측정(IRMA)키트를 이용하여 측 정하였다.

결과: 성장호르몬자극검사를 시행한 68 명의 소아 중 25 명이 성장호르몬 결핍증으로 진단되었고 이 중 15명(15/25, 60\%)에서 IGF-I이 감소되었고, 4명(4/25, 16\%)에서 IGFBP-3가 감소되어 있었 다. IGF-|과 IGFBP-3의 민감도는 각각 $60 \%, 16 \%$ 이었고, 특이도는 $41.9 \%, 97.7 \%$ 이었다.

결론: IGF-I과 IGFBP-3의 혈중농도는 저신장증 소아의 성장호르몬 결핍증에 대한 선별검사로 사 용되고 있지만, 성장호르몬자극검사로 확인한 결과 성장호르몬 혈중농도에 대한 지표로써의 유용 성이 있다고 할 수 없었다. IGF-|의 감소빈도는 원인에 관계없이 신장 25 백분위수 미만인 소아에서 25-95백분위수 소아에 비해 의미 있게 높았으나 저신장증의 선별검사로써의 이용하기는 어렵다고 판단하였다.

(J Lab Med Qual Assur 2014;36:48-53)

\section{교신저자: 문연숙}

우)400-711 인천시 중구 인항로 27 , 인하대병원 진단검사의학과

Tel: 032)890-2523 Fax: 032)890-2529 E-mail: moonys@inha.ac.kr

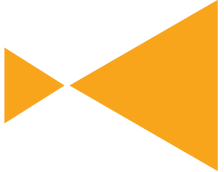

Journal of LABORATORY MEDICINE and

QUALITY ASSURANCE 